\title{
Assessment of hazards and risks in glass products production and processing business during the pandemic
}

\section{Pandemi sürecinde cam ürünleri üretim ve işleme işletmelerinde tehlike ve risklerin değerlendirilmesi}

\author{
İhsan Ateş 1,*(D), Serdar Salman² (D), Yahya Bozkurt ${ }^{3}$ (iD \\ ${ }^{1}$ Department of Occupational Safety, Institute of Science, Marmara University, Istanbul, Turkey \\ ${ }^{2,3}$ Department of Metallurgical and Materials Engineering, Faculty of Technology, Marmara University, Istanbul, Turkey
}

\begin{abstract}
In this study, the hazards in a medium-sized enterprise engaged in production and processing of glass products in Turkey and the risks they pose are identified. Then, using cross-sectional research, a physical, chemical and biological risk report was created by L-type matrix method. During this reporting, hazards caused by Covid-19, which has been declared as pandemic by World Health Organization and became the biggest health problem in the world today, and regulatory and preventive actions that can be taken against these hazards are widely covered. The aim of the study is to contribute to the industry in terms of taking measures against occupational accidents and diseases.
\end{abstract}

Anahtar kelimeler: Glass industry, Occupational safety, Hazard, Risk analysis, Covid-19, Pandemic

\section{Introduction}

Throughout their journey of survival in the cycle of life, people have to perform some certain actions mandated by the life itself such as working, producing, having fun and exercising. Observed in every aspect of life, the role and the significance of "safety" in working life date back to the beginning of the mechanized industrialization in Europe during the 18th and 19th centuries. As a result of the analysis of the occupational accidents and diseases experienced at the beginning of the industrialization era, certain measures taken to prevent the recurrence of such have lead the process to a reactive course of actions. Taking the occupational accidents and occupational diseases occurring through the course of the mechanization process into consideration, the concept of occupational safety becomes prominent and have lead into changes in design of the machines. Every change brings about the prevention culture and the process is ensured to be proactive. When industrialization in the world is analyzed, from the very beginning until today, the concept of safety culture has developed through its natural course and works have been conducted in order to create a safe working environment in light of technological advances [1].

Occupational Health and Safety (OHS) has taken its place among important concepts of today's business life. Works conducted and steps taken in the OHS field have
Özet

Bu çalışmada, Türkiye'de cam ürünleri üretimi ve işlemesi yapan orta ölçekli bir işletmedeki tehlikeler ve bunların oluşturduğu riskler tespit edilmiştir. Daha sonra kesitsel araştırma kullanılarak L tipi matris yöntemi ile fiziksel, kimyasal ve biyolojik bir risk raporu oluşturulmuştur. Bu raporlama sirasında Dünya Sağlık Örgütü tarafindan pandemi ilan edilen ve bugün dünyanın en büyük sağlık sorunu haline gelen Covid-19'un neden olduğu tehlikeler ve bu tehlikelere karşı alınabilecek düzenleyici ve önleyici tedbirler geniş kapsamlı olarak ele alınmaktadır. Çalışmanın amacı, iş kazası ve meslek hastalıklarına karşı önlem alma konusunda sektöre katkı sağlamaktır.

Keywords: Cam endüstrisi, İş güvenliği, Tehlike, Risk analizi, Covid-19, Pandemi

positive impacts on the change in safety culture. OHS professionals focus on adult training and habit-breaking subjects, thus making significant contributions to the awareness-raising and the improvement of safety culture levels of employees. The involvement of workers in activities such as trainings, improper implementations detected during audits, risk assessments of workers plays an active role in the prevention of occupational accidents and diseases. With the OHS Law no. 6331 (OHSL) going into effect, OHS-related works conducted almost in all industries in Turkey have accelerated, and statistics have started to be followed on a sectoral basis. Following the enforcement of OHSL no. 6331, reactive methods have been replaced by proactive methods. Proactive approach is a system that aims to prevent possible accidents and diseases by determining the hazards in the activities carried out in the work environment in advance. As an output of this system, it is aimed to take measures against the risks posed by hazards in the work environment analyzed, and to prevent the possible accidents and diseases by analyzing in advance. There are many different methods developed and implemented in terms of hazard and risk identification. As a result of the implementation of these methods, a corrective and preventive approach was adopted rather than a prescriptive approach [2].

\footnotetext{
* Sorumlu yazar / Corresponding author, e-posta / e-mail: ihsanates @hotmail.com (İ. Ateş)

Geliș / Recieved: 04.02.2021 Kabul / Accepted: 16.03.2021 Yayımlanma / Published: 27.07.2021

doi: $10.28948 /$ ngmuh.874295
} 
As of 1990s, numerous studies have been conducted in terms of hazards and risks which may be encountered by glass industry workers. Some of these studies have been conducted on the risk of cancer among glass factory workers [3], occupational glass injury risk of bar staff [4], diabetic and arsenic-based health problems of artistic glass workers [5-8], injuries at glass bottle production facilities [9], exposure to occupational styrene in glass fiber reinforced plastic industry and skin diseases $[10,11]$, review and metaanalysis of risks related to rockwool and glass wool exposure of lung, head and neck cancers [12].

Glass industry with all of its sub-industries is a sector in hazardous and very hazardous class due to chemical raw materials, work equipment used during production, Covid19 which has become today's biggest health problem as well as physical, chemical and biological hazards, and it harbors significant hazards and relevant risks in terms of OHS. In this study; hazards within the work environments of glass and glass product enterprises, the risks they may create are identified, risk analysis of the enterprise is created using Ltype matrix risk assessment method, and recommendations and actions required for measures to be taken are defined.

\section{Glass and glass products industry}

Glass is one of the oldest forms of artificial materials discovered by humankind. During the prehistoric ages, humans used volcanic glass, found in nature, to construct arrowheads and cutting tools although they did have the knowledge of how glass was produced. The first glass produced by humans is thought to be the beads made in Mesopotamia and Egypt in 2500 BC [13].

While almost all kinds of glass products were handcrafted until the end of the 19th century [14], today, all glassworks except certain special parts are produced by machines. Glass, thanks to its natural state of transparency, constant volume, odorless and tasteless form, and resistance to numerous chemicals is an industrial field that provides input to almost all industries such as food, beverage, medicine, cosmetics, architecture, health, automotive, construction, communication, white goods, machinery, furniture, electric-electronics and glassware.

Glass industry production capacity in Turkey is approximately 3.5 million tons. The industry, supplying almost all of its production inputs from domestic sources, is obliged to maintain its energetic, intensive and high-capacity operation activities with its production value of approximately 2 billion dollars and 20 thousand employees [15].

\section{Place of glass and glass products production in Turkey}

Turkish Glass Industry, founded in 1934 upon the order of Atatürk, has increased its production capacity day by day in parallel with technological advances, and become one of the most significant branches of Turkish manufacturing industry today thanks to its product quality, increasing export figures and being an industry, which supplies all of its production inputs from domestic sources.

5-years import and export figures for glass and glassware products are given below. Turkey's top export items are tableware, ornaments, flat glass and fibers. According to 2023 Export Strategy of Turkey Exporters Assembly, 2023 export target for glass and glass products industry is 2.5 billion dollars [15]. It is estimated that global annual glass production capacity is approximately 180 million tons and has a value of approximately 130-140 billion dollars. Global glass industry grows between $2-4 \%$ on average every year based on the advances in the global economy. 53\% of this belongs to glass packages, $29 \%$ to flat glass, $5 \%$ glass houseware, $2 \%$ to glass fiber and $11 \%$ to other products [15].

Table 1 shows glass and glass products import figures between 2013-2019. According to this, most of the imports are made from China. China is followed by Germany and Bulgaria. Import of glass items from China, solely, is more than the total of import from the subsequent countries.

Table 2 shows export figures of glass and glass products industry. Germany is in the first place, followed by Italy, USA and France. Despite ranking the first in 2015 and 2016, Italy dropped to the second place in 2017 and 2018.

Table 1. Countries from which Turkey imports glass products and import amounts (1000 USD) [16]

\begin{tabular}{lcccccc}
\hline & & \multicolumn{3}{c}{ Yearly Import Amounts } \\
Imported Countries & 2013 & 2014 & 2015 & 2016 & 2017 & 185.235 \\
China & 237.581 & 238.476 & 223.749 & 202.222 & 164.474 \\
Germany & 78.179 & 84.057 & 71.809 & 73.456 & 80.100 & 85.832 \\
Bulgaria & 25.815 & 36.413 & 43.465 & 51.264 & 61.793 & 64.822 \\
Italy & 42.765 & 63.912 & 45.284 & 52.720 & 68.368 & 58.695 \\
France & 47.816 & 48.398 & 45.606 & 47.017 & 51.137 & 51.143 \\
USA & 32.341 & 37.881 & 42.858 & 39.434 & 50.253 & 47.058 \\
\hline
\end{tabular}

Table 2. Countries to which Turkey exports glass products and export amounts (1000 USD) [16]

\begin{tabular}{|c|c|c|c|c|c|c|c|}
\hline \multirow{2}{*}{ Exported Countries } & \multicolumn{7}{|c|}{ Yearly Export Amounts } \\
\hline & 2013 & 2014 & 2015 & 2016 & 2017 & 2018 & 2019 \\
\hline Germany & 103.519 & 115.313 & 89.760 & 84.898 & 90.955 & 92.161 & 85.670 \\
\hline Italy & 59.333 & 60.901 & 160.220 & 120.960 & 60.403 & 71.908 & 91.813 \\
\hline USA & 38.801 & 46.765 & 42.870 & 42.688 & 44.023 & 47.717 & 53.796 \\
\hline France & 57.537 & 55.265 & 59.654 & 49.842 & 42.902 & 47.543 & 50.705 \\
\hline United Kingdom & 55.153 & 59.186 & 82.914 & 46.705 & 54.034 & 47.369 & 57.558 \\
\hline
\end{tabular}




\section{Risk assessment methods}

The word "risk" derives from the words risq in Arabic or risicum in Latin [17]. According to [18], risk is the probability of not achieving a targeted result or probability of the occurrence of an undesired incident, and uncertainties are potential sources of risk [18]. Risk is an objective concept related to the uncertainty of occurrence of unwanted incidents [18]. Throughout years, various risk assessment models have been conceptualized in order to elucidate the concept of the safety risk assessment $[19,20]$. Through proactive approach, risk assessments are performed at enterprises in order to identify the risks and take the required measures before the accident occurs [21, 22].

Following are the different (qualitative, quantitative and mixed) risk assessment methods applied in calculation of risk score [23]:

- Process Hazard Analysis (PHA)

- Probabilistic Risk Assessment (PRA)

- Probabilistic Risk Assessment Using Checklist (PRA Using Checklist)

- Fine - Kinney Method

- Safety Audit

- Rapid Ranking Methodology

- Job Safety Analysis (JSA)

- Canonical-Correlation Analysis (CCA)

- Failure Mode and Effects Analysis Methodology (FMEA)

- Event Tree Analysis (ETA)

- What If Analysis (What If)

- Risk Assessment Decision Matrix Methodology (L-shaped, X-shaped)

- Risk Map

- Hazard Rating Method (DOW, MOND Index)

- Hazard and Operability Study Methodology (HAZOP)

\subsection{L-type matrix method}

Statistics of occupational diseases and accidents in the industry, field workers and OHS professionals are used in order to assess the hazards and risks encountered in glass and glass products production. In conclusion, it has been observed that employees are exposed to physical, chemical, biological, psychosocial, ergonomic hazards and risks along the line from the raw material preparation stage until the shipping process.

In L-type matrix risk assessment method, it is aimed to reach the risk score result by assessing the probability of the hazardous situation along with the impact of the damage. Corrective and preventive actions are implemented in accordance with the equivalent of the risk score, which is found as a result of mathematical multiplication of the values obtained, in the score table [14].

Values indicating the probability and severity of the incident or hazardous situation subject to the assessment are selected from Table 3, multiplied, and the result determines the risk score.
Table 3 indicates how to value and score the ranking/severity and the probability of risks when conducting a risk analysis. Risks that do not cause incapacity or require first aid are assessed as very light in terms of ranking/severity and scored 1 , while situations that may require first aid or outpatient treatment are considered light and scored 2. Death and mass death events are ranked as very serious and scored 5. Probability of risks that almost never occur are defined as highly unlikely and given 1 as the score while risks that occur every day or once a week are identified as very likely and assessed with a score of 5 .

\subsection{Risk score assessment}

Concepts to be used for risk score assessment can be defined as follows:

Risk: Probability of loss, injury or other harmful results caused by the hazard.

Risk Score: Value found as a result of mathematical multiplication of probability, frequency and severity.

Severity: Severity of results in case of an accident.

Hazard: Potential of causing loss or damage, either originating from the workplace itself or the outer environment, that may affect the worker or workplace [25].

Assessment of resultant risk [26] score is conducted according to Table 4 and Table 5, and corrective and preventive actions are taken. As seen in Table 4, risk score is obtained by multiplying risk rating/severity and probability values. For instance, score of a risk with moderate rating/severity and moderate probability is found to be $3 \times 3$ $=9$. The score found is assessed as seen in Table 5. This table shows the rating of risk and the resulting assessment accordingly. The higher risk score, the more important the actions to be taken. If risk score is 25 as a result of the actions taken, it is assessed as "unacceptable risk". In this case, required measures must be taken immediately, or it must be considered to close the facility, building and environment. If the risk score is between 1 and 5 , it is considered as "probable risk" and observation practices continue

\subsection{Identification of hazards and risks}

Glass industry is in "very hazardous" class due to its production stages and the chemical substances used. Glass is broken or crushed during the raw material preparation stage and concentrated in blend preparation section. This is where, glass and other various alloy elements and chemical substances interfuse. Measures must be taken against chemical dusts that may be released in this process. Release of these dusts to the environment may cause lung disease. The blend in solid phase prepared during fusion stage is transformed to liquid phase and given the capability to change form. In this stage, various measures must be taken against thermal comfort conditions and chemical vapor. Materials coming out of the kiln are shaped by pressure or force in the forming unit, checked after cooling process, and sent to the warehouse. Each stage has its own specific hazards and risks [15]. 
Table 3. Table for rating/severity and probability values in risk analysis [24]

\begin{tabular}{|c|c|c|c|}
\hline \multicolumn{2}{|r|}{ Ranking / Severity } & \multicolumn{2}{|r|}{ Probability } \\
\hline $\begin{array}{c}1 \\
\text { Very Light }\end{array}$ & Does not cause incapacity or require first aid. & $\begin{array}{c}1 \\
\text { Very Low }\end{array}$ & $\begin{array}{l}\text { Not expected to occur during the process. Sufficient control is ensured. } \\
\text { (Almost never) }\end{array}$ \\
\hline $\begin{array}{c}2 \\
\text { Light }\end{array}$ & $\begin{array}{l}\text { Situations that may require first aid, outpatient } \\
\text { treatment. }\end{array}$ & $\begin{array}{l}2 \\
\text { Low }\end{array}$ & $\begin{array}{l}\text { It is thought that the probability during the process is eliminated. Control } \\
\text { system available. (Once in a few years) }\end{array}$ \\
\hline $\begin{array}{l}3 \\
\text { Moderate }\end{array}$ & $\begin{array}{l}\text { Injuries requiring treatment, inpatient treatment, } \\
\text { short-term incapacity. }\end{array}$ & $\begin{array}{l}3 \\
\text { Moderate }\end{array}$ & $\begin{array}{l}\text { Probable to occur during the process, however it is not expected. Its } \\
\text { uncontrollability is a very slight probability. (Once or twice a year) }\end{array}$ \\
\hline $\begin{array}{l}4 \\
\text { Serious }\end{array}$ & $\begin{array}{l}\text { Sever injuries, loss of limb, occupational disease, } \\
\text { continuous incapacity. }\end{array}$ & $\begin{array}{c}4 \\
\text { High }\end{array}$ & $\begin{array}{l}\text { Likely to occur during the process. Its controllability is not certain, or } \\
\text { controls might be limited and insufficient (Once a month) }\end{array}$ \\
\hline $\begin{array}{l}5 \\
\text { Very Serious }\end{array}$ & Death, Mass Death. & $\begin{array}{l}5 \\
\text { Very High }\end{array}$ & $\begin{array}{l}\text { Expected to occur during the process. No control system. (Once a } \\
\text { week/Every day) }\end{array}$ \\
\hline
\end{tabular}

Table 4. Risk score assessment [24]

\begin{tabular}{|c|c|c|c|c|c|c|}
\hline & & \multicolumn{5}{|c|}{ Ranking / Severity } \\
\hline & & $\begin{array}{c}\text { Very Serious } \\
5\end{array}$ & $\begin{array}{c}\text { Serious } \\
4\end{array}$ & $\begin{array}{c}\text { Moderate } \\
3\end{array}$ & $\begin{array}{l}\text { Light } \\
2\end{array}$ & $\begin{array}{c}\text { Very Light } \\
1\end{array}$ \\
\hline \multirow{9}{*}{ 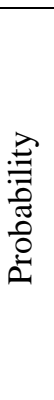 } & $\begin{array}{l}\text { Very High } \\
5\end{array}$ & $\begin{array}{c}\text { Unacceptable } \\
25\end{array}$ & $\begin{array}{l}\text { High } \\
20\end{array}$ & $\begin{array}{c}\text { High } \\
15\end{array}$ & $\begin{array}{c}\text { Moderate } \\
10\end{array}$ & $\begin{array}{c}\text { Moderate } \\
5\end{array}$ \\
\hline & High & High & High & Moderate & Moderate & Low \\
\hline & 4 & 20 & 16 & 12 & 8 & 4 \\
\hline & Moderate & High & Moderate & Moderate & Moderate & Low \\
\hline & 3 & 15 & 12 & 9 & 6 & 3 \\
\hline & Low & Moderate & Moderate & Moderate & Low & Low \\
\hline & 2 & 10 & 8 & 6 & 4 & 2 \\
\hline & Very Low & Moderate & Low & Low & Low & Irrelevant \\
\hline & 1 & 5 & 4 & 3 & 2 & 1 \\
\hline
\end{tabular}

Table 5. Risk assessment results [24]

\begin{tabular}{|c|c|c|}
\hline Risk Value & Risk Ranking & Risk Assessment Result \\
\hline$x=25$ & 1st Degree & $\begin{array}{l}\text { Unacceptable risk required measures must be taken immediately / or it must be considered to close the facility, } \\
\text { building and environment }\end{array}$ \\
\hline $12<x<25$ & 2nd Degree & Very important risk must be improved in the short run (within a few months) \\
\hline $6<x<15$ & 3rd Degree & Important risk must be improved in the long run (within the year) \\
\hline $1<x<15$ & 4th Degree & Probable risk must be implemented under surveillance \\
\hline$x=1$ & 5th Degree & Unimportant risk measures are non-priority \\
\hline
\end{tabular}

Required safety measures must be taken for chemicals used in glass production, and material safety data forms (MSDSs) of chemicals must be obtained. Forced and natural ventilation systems must be used in areas where toxic chemicals which are harmful for respiration are processed, environmental measures must be performed in required intervals. Appropriate mask use must be ensured in sections where there is no sufficient ventilation and dusty areas. Combustible and caustic materials must not be placed in the same environment, employees must be trained against possible fires, and appropriate fire extinguishers must be provided. Noisy work areas must be isolated from other departments, and appropriate protective earpieces must be used by employees exposed to noise. Working hours of employees exposed to continuous loud noises must be regulated and suitable resting breaks must be scheduled [27]. Appropriate personal protection gears must be provided and used in order to protect employees during processes where the glass is formed by blowing. Appropriate heatproof and noncombustible gloves must be provided to persons who are constantly exposed to high temperatures, and direct contact of eyes and skin with heat must be avoided. Employees must hydrate sufficiently and working hours must be regulated appropriately. Ventilation and cooling systems must be constructed suitably [28]. Relevant training must be provided, and suitable transport vehicles must be used in order to prevent accidents that may occur during the conveyance of materials. Appropriate gloves, clothes, and face protector's resistant to cutting must be used in order to be protected from "cutting" feature of broken glass, and 
manual handling procedures must be replaced with automation system as much as possible [14].

\subsection{Risk factors}

When we take a look at the risks that may occur after the hazards arising within the scope of occupational health and safety, risk factors may be listed as follows [28]:

- Physical risk factors: Noise, vibration, lighting, heat, humidity, dusts, radiation, pressure, etc.

- Chemical risk factors: Mines, solvents, toxic gases, acid and alkalis, pesticides, plastic substances, dusts, etc.

- Biological risk factors: Bacteria, viruses, parasites, brucella, anthrax, plague, tularemia, etc.

- Psychosocial risk factors: Job security, future concerns, long working hours, work stress, severity, time pressure, job dissatisfaction, monotone work, rareness of resting breaks, etc.

- Ergonomic risk factors: Physiology of the work, heavy load handling and lifting, etc.

\subsubsection{Physical risk factors}

Valve actuator devices, mixer engines, vibrators, dust collectors and blowing machines operating with loud noises are machines that are frequently used in glass production. Workers who use or work in the vicinity of these machinery may experience loss of hearing due to noise when they are exposed to loud noise for a long time [29].

Since fusion process is generally conducted in closedsystem furnaces, there are no employees in this section where this process takes place. However, since molten glass is taken out from kilns to be processed in enterprises conducting manual production, employees may be exposed to high temperatures [30]. Severe burns may occur on the skin due to high temperatures. Infrared lights may harm the eyes if measures are not taken, also the risk of cataract increases for people who are exposed to this heat for a long time. In addition, people who are exposed to high temperatures for a long time may experience heat strokes. Heat stroke may cause fatigue, drop in blood pressure, nausea, vomiting as well as fever, respiratory failure, and loss of consciousness in later stages. High temperature may also cause attention deficit of the employee and thus may lead to occupational accidents [31].

Since cooling process is performed on automated belts, the risks in this section are relatively less than others. However, noise exposure is also very high in this section.

Employees may experience musculoskeletal system disorders during packaging and transport of glasses produced with different forms and weights. In this section, especially glass shards pose risks. Also, there may be risks caused by forklifts and pallet trucks used for transport.

\subsubsection{Chemical risk factors}

There are numerous chemical compounds bearing features of glass. Breathing the air contaminated with the vapor of chemicals used in glass production such as silica, clay, limestone, aluminum oxide, and heavy metals might cause health-related hazards can cause health problems.
Paints used during changing the color of the glass vaporize more since they are applied on hot glass. Respiration of vaporized chemicals may cause pneumoconiosis and lung diseases. The risk of lung cancer increases in employees who have been exposed to vapors of chemicals for long years [31]

The process during which the glass is rapidly crashed to an abrasive and hard ground in order to smooth out or swell the glass surface is called blasting. During blasting, silica crystals are mixed into the air and may cause silicosis in lungs as a result of the air breathed. Heavy metals are added to the mixture used for production of frit and coloring of the frit. Respiration of the metal smoke may cause lead poisoning. A person who suffers from lead poisoning may experience anemia, headache and even coma and death in later stages. In glass material production where the glass is shaped by blowing, the blower may be exposed to chemical vapors. The blower may experience kidney function deformations and respiratory tract diseases such as bronchopneumonia and bronchitis as a result of inhaling metals such as mercury [32].

Despite majority of the process is performed by automated system in large-scale production factories, these kinds of exposures are experienced while taking samples from production, during repairment of system failures, and as a result of employee faults and unavoidable accidents.

\subsubsection{Biological risk factors}

In crowded enterprises where the number of employees is high, biological hazards are risk factors required to be taken into consideration. Biological agents include bacteria, viruses, fungi, other microorganisms and related toxins. These organisms which are (or products of) living creatures are generally found in natural environments such as water, soil, plants and animals. When talking about biological risk factors in working life, microorganisms, cell cultures and human parasites which may cause any infection, allergy or poisoning (including genetically modified ones) come to mind $[33,34]$.

European Directive 2000/54/CE classifies biological hazards (pathogens) into four groups based on infection risk level [35]:

Group 1: Unlikely to cause human disease;

Group 2: Can cause human disease and might be a hazard to workers; unlikely to spread to the community; there is usually effective prophylaxis or treatment available;

Group 3: Can cause severe human disease and present a serious hazard to workers; it may

present a risk of spreading to the community, but there is usually effective prophylaxis or treatment available;

Group 4: Causes severe human disease and is a serious hazard to workers; it may present a high

risk of spreading to the community; there is usually no effective prophylaxis or treatment available.

Under Group 3, Covid-19 pandemic, which is thought to be originated from Huanan Seafood and Live Animal Market in Wuhan city of Hubei state of China in December 2019 for the first time and has caused a pandemic 
throughout the world, continues to pose vital threats [36]. These risks caused by the pandemic affect the whole world, thus negatively changing the working life in our country too. Certain hazards caused by Covid-19 and corrective and preventive actions that can be taken against these hazards are given in Table 6.

\subsubsection{Psychosocial risk factors}

It has been observed that identification and diagnosis of psychosocial risk factors in workplaces is difficult, it is challenging to access previous records, and even when accessed, very limited in Social Security Institution. It is difficult to diagnose occupational diseases based on psychosocial factors. Because, establishing causal relation between the disease and the work or the working environment, and understanding whether it is caused by the occupation is a rather difficult process compared to other diseases [37].

Psychosocial factors include subjects such as relationships between people in a workplace, relations of employees with each other, with foremen, headmen and directors, management form and renumeration policy of the workplace. Also, work stress and similar issues caused by heavy, repetitive and monotone works can be examined under this title. Primary psychosocial factors include stress, which is described as the disease of our age by certain circles, as well as conflicts and organizational factors (working hours, shifts, etc.) [38].

\subsubsection{Ergonomic risk factors}

Ergonomics is defined as designing workplaces, equipment, machinery, apparatus, products, environments and systems appropriate for the employee by optimizing the efficiency and effectiveness of work systems, taking into consideration physical, physiological, biomechanical and psychological characteristics of humans $[39,40]$.

\section{Research methods and results}

In this study, a medium-scale enterprise engaged in the production and processing of glass products in Turkey is examined cross-sectionally [41]. Prior to the study, a risk analysis team was established consisting of one head labor inspector, two class A occupational safety specialists, two class B occupational safety specialists, one workplace physician and employer representative, employee representative, head of the department, and supporting staff. Risk analysis methods were examined with team members, and the L-type matrix risk analysis method was preferred as the risk analysis method to be applied in the workplace. Information related to the L-type matrix risk analysis was conveyed to team members through training, afterwards, field inspections were conducted and required statistical data was collected for a month. Near miss incidents and accident reports of the subject enterprise were examined in detail by team members. The findings obtained were assessed in accordance with the L-type matrix risk analysis method, and risk analysis of the firm was created. Required measures were taken, field observations were repeated, and risk analysis was revised following this risk analysis.

Table 6 identifies the hazard sources in the enterprise and reveals the risks that may be caused by these hazards. In the resulting risk analysis, 37 activities with the highest risk score are listed. Probability, severity, and risk scores are shown based on existing conditions in these cases. Priorities are detected based on scores, and recommendations about the measures to be taken are listed. Risk scores of activities numbered 1, 2, 3, 4, 5, 6 and 7 are found to be 25 . Immediate measures must be taken for identified hazards. Risk scores of other activities given in the table are found to be 15-20. Recommendations are provided, and measures to be taken are identified also for these activities.

\section{Conclusion}

Hazards and risks based on physical, chemical and biological factors which the employees can be exposed to during the production process of an enterprise engaged in glass and glass products industry were identified. The risks identified were proactively assessed, and corrective and preventive measures were identified for each activity. Preventive and corrective actions identified for 37 activities with high risk scores as a result of the study must be immediately processed, and a probable unwanted situation must be prevented. Among the hazards identified in the table, it has been found that hazards such as pandemic, electrical panels, machinery, moving parts, working at height, chemical substances and fire had the highest risk scores. In order to prevent occupational accidents before they happen, measures required to be taken in terms of activities centered around people must be realized immediately. Therefore, actions must be taken with the motto "People First", and risks must be eliminated at source before they occur. In conclusion, the study conducted is significant as it constitutes a leading model for enterprises engaged in glass and glass products industry and scientists who will conduct studies in this field.

\section{Acknowledgement}

This research did not receive any specific funding.

\section{Conflict of interest}

The authors declare no conflicts of interest.

\section{Similarity Rate (iThenticate): $8 \%$}


Table 6. Risk assessment with L-type matrix method (P: Probability, S: Severity, RS: Risk score)

\begin{tabular}{|c|c|c|c|c|c|c|c|c|}
\hline No & Department & Hazard & $*$ Probability / **Risk & Current Situation & $\mathrm{P}$ & $S$ & R S & $\begin{array}{c}\text { Recommendations/Measures to be } \\
\text { Taken }\end{array}$ \\
\hline 1 & General & $\begin{array}{l}\text { Coronavirus } \\
\text { pandemic }\end{array}$ & $\begin{array}{l}\text { *Exposure to coronavirus } \\
\text { pandemic. } \\
* * \text { Infection, disability, death. }\end{array}$ & $\begin{array}{l}\text { Covid-19 virus, which } \\
\text { spreads very rapidly, } \\
\text { has been declared a } \\
\text { pandemic by World } \\
\text { Health Organization } \\
\text { (WHO). }\end{array}$ & 5 & 5 & 25 & $\begin{array}{l}\text { Employees and visitors ( } 37.5 \mathrm{C} \text { and } \\
\text { above) must be prevented from entering } \\
\text { the enterprise and referred to the nearest } \\
\text { health institution. Infrared, contactless } \\
\text { temperature meter must be used to take } \\
\text { temperature at the enterprise. }\end{array}$ \\
\hline 2 & General & $\begin{array}{l}\text { PPEs which are not } \\
\text { sufficient or } \\
\text { appropriate for } \\
\text { coronavirus } \\
\text { pandemic and lack of } \\
\text { disinfectants in }\end{array}$ & $\begin{array}{l}\text { *Exposure to coronavirus } \\
\text { pandemic. } \\
* * \text { Infection, disability, death. }\end{array}$ & $\begin{array}{l}\text { It has been found that } \\
\text { masks are used, } \\
\text { however are not } \\
\text { replaced periodically. }\end{array}$ & 5 & 5 & 25 & $\begin{array}{l}\text { It is required to increase stocks of } \\
\text { masks (TS EN95, EN149, FFP2, FFP3), } \\
\text { gloves (latex gloves, EN ISO 374-5), } \\
\text { bleach, alcohol, cologne ( } 80 \text { degrees), } \\
\text { hand disinfectants. }\end{array}$ \\
\hline
\end{tabular}

stocks

Not respecting It has been found that

3 General individual safe *Exposure to coronavirus employees do not

distance or close pandemic. respect social distance

contact due to **Infection, disability, death. rules in the cafeteria. coronavirus

pandemic

4 General

Lack of hygiene *Exposure to coronavirus

training

employees

of pandemic.

** Infection, disability, death.

It has been understood

that the employees

were not given

required trainings in

terms of pandemic

process.

Employees over $65 *$ Exposure to coronavirus Covid-19 virus, which and with chronic pandemic.

5 General diseases due to **Infection, disability, death. coronavirus pandemic spreads very rapidly, has been declared pandemic by World

Health Organization (WHO).

People over 65, individuals with chronic diseases, pregnant women, disabled individuals and employees who require special policies must be isolated (home office, leave, etc.)

Insulating mats must be placed under *Lack of insulating mat under Required warning 5,5 Insulating mats must be placed under the electrical panel / wetness signs are not $\begin{array}{lllll}5 & 5 & 25 & \text { floor cannot be dried, insulating mat }\end{array}$ under the panel.

**Electric shock, serious injury, available. must be positioned in a way to prevent contact of the insulating mat with water.

Electrical

7 Panels

Electrical Wiring burn, death. $\begin{array}{ll}* \text { Lack of leakage current relay } & \text { Leakage current relay } \\ * * \text { Electric shock, death. } & \text { is defective. }\end{array}$

is defective.

Leakage current relays must be present at main boards (300Ma) and secondary boards (30Ma).

Not observing individual safe

8 General distance or close contact due to pandemic. coronavirus pandemic, and lack of remote communication during meetings

Common Use Areas

*Employees becoming infected.
It has been detected that teleconference method is not used commonly for trainings and meetings.
$4 \quad 520$ Interviews and meetings must be conducted via remote communication. **Spread of infection, disability, death.

It has been detected that there is no $4 \quad 5 \quad 20$

disinfestation checklist in locker rooms.

It has been detected

*Employees becoming infected. that metal and class ** Spread of infection, disability, death. materials are used in 4 the cafeteria. 
Table 6. (Continued)

\begin{tabular}{|c|c|c|c|c|c|c|c|c|}
\hline No & Department & Hazard & $*$ Probability / **Risk & Current Situation & $\mathrm{P}$ & $\mathrm{S}$ & R S & $\begin{array}{c}\text { Recommendations/Measures to be } \\
\text { Taken }\end{array}$ \\
\hline 11 & General & $\begin{array}{l}\text { Machinery and } \\
\text { equipment used in } \\
\text { common }\end{array}$ & $\begin{array}{l}\text { *Employees becoming infected. } \\
\text { **Spread of infection, disability, } \\
\text { death. }\end{array}$ & $\begin{array}{l}\text { Covid-19 virus, which } \\
\text { spreads very rapidly, } \\
\text { has been declared a } \\
\text { pandemic by WHO. }\end{array}$ & 4 & 5 & 20 & $\begin{array}{l}\text { Machinery and equipment must be } \\
\text { disinfested periodically. }\end{array}$ \\
\hline 12 & General & Machinery & $\begin{array}{l}\text { *Lack of instructions of use for } \\
\text { machinery. } \\
* * \text { Serious injury, long-term } \\
\text { treatment. }\end{array}$ & $\begin{array}{l}\text { Machines lack } \\
\text { instructions of use. }\end{array}$ & 5 & 4 & 20 & $\begin{array}{l}\text { Machines without instructions must not } \\
\text { be used and instructions must be } \\
\text { prepared immediately }\end{array}$ \\
\hline 13 & Shipping & Working at height & $\begin{array}{l}\text { *Lack of guardrails on the side of } \\
\text { ramps. } \\
* * \text { Falling from height, serious } \\
\text { injury. }\end{array}$ & $\begin{array}{l}\text { There are no } \\
\text { guardrails on the sides } \\
\text { of ramps despite the } \\
\text { area is suitable for } \\
\text { guardrail } \\
\text { construction. }\end{array}$ & 5 & 4 & 20 & $\begin{array}{l}\text { The area around the ramps that would } \\
\text { cause falling from height must be } \\
\text { covered } 50 \mathrm{~cm}-100 \mathrm{~cm} \text { from the } \\
\text { ground with guardrail protection. }\end{array}$ \\
\hline 14 & Shipping & $\begin{array}{l}\text { Moving vehicles and } \\
\text { machinery (Shipping } \\
\text { area) }\end{array}$ & $\begin{array}{l}\text { *Lack of protective enclosures } \\
\text { of ramp pistons. } \\
* * \text { Jamming of limbs, serious } \\
\text { injury. }\end{array}$ & $\begin{array}{l}\text { Ramp pistons do not } \\
\text { have protective } \\
\text { enclosures. }\end{array}$ & 5 & 4 & 20 & $\begin{array}{l}\text { Ramp pistons must be supported with } \\
\text { protective enclosures, and manual } \\
\text { interventions of personnel must be } \\
\text { prevented. }\end{array}$ \\
\hline 15 & $\begin{array}{l}\text { Empty Tube } \\
\text { Storage } \\
\text { Area }\end{array}$ & $\begin{array}{l}\text { Explosion (Empty } \\
\text { tube stock area) }\end{array}$ & $\begin{array}{l}\text { *Doors being open, tubes being } \\
\text { not fixes. } \\
\text { **Explosion, serious injury, } \\
\text { death. }\end{array}$ & $\begin{array}{l}\text { Tubes are not fixed } \\
\text { separately as empty- } \\
\text { full. }\end{array}$ & 4 & 5 & 20 & $\begin{array}{l}\text { Tubes in empty tube area must be fixed } \\
\text { and its door must be kept locked. }\end{array}$ \\
\hline 16 & Waste Area & $\begin{array}{l}\text { Electricity } \quad \text { (Fuse } \\
\text { box) }\end{array}$ & $\begin{array}{l}\text { *Lack of electric panel cover. } \\
* * \text { Electric shock, severe injury, } \\
\text { burn, death. }\end{array}$ & $\begin{array}{l}\text { Cover of electric } \\
\text { panel is not mounted. }\end{array}$ & 4 & 5 & 20 & $\begin{array}{l}\text { Fuse box cover must be mounted in } \\
\text { order to ensure that it is not affected } \\
\text { from possible weather conditions. }\end{array}$ \\
\hline 17 & Roof & $\begin{array}{l}\text { Working at height } \\
\text { (Roof climbing area) }\end{array}$ & $\begin{array}{l}\text { *Lack of lock at the stairs. } \\
* * \text { Falling from height, injury, } \\
\text { death. }\end{array}$ & $\begin{array}{l}\text { The stair has a lock } \\
\text { mechanism but is not } \\
\text { locked. }\end{array}$ & 4 & 5 & 20 & $\begin{array}{l}\text { The stairs used to climb to the roof } \\
\text { outside the factory must be locked in } \\
\text { order to prevent it from being used by } \\
\text { unauthorized personnel without safety } \\
\text { measures. }\end{array}$ \\
\hline 18 & General & $\begin{array}{l}\text { Coronavirus } \\
\text { pandemic, } \\
\text { inappropriate } \\
\text { conditions for hand } \\
\text { hygiene }\end{array}$ & $\begin{array}{l}\text { *Exposure to coronavirus } \\
\text { pandemic. } \\
\text { **Infection, disability, death. }\end{array}$ & $\begin{array}{l}\text { It has been found that } \\
\text { there is sufficient } \\
\text { amount of liquid soap } \\
\text { at toilets. It has been } \\
\text { detected that alcohol- } \\
\text { based disinfectants are } \\
\text { not present in every } \\
\text { area. }\end{array}$ & 4 & 5 & 20 & $\begin{array}{l}\text { Attention must be paid to hand hygiene, } \\
\text { hands must be washed with soap and } \\
\text { water for at least } 20 \text { seconds, and hand } \\
\text { sanitizers with } 70-80 \% \text { alcohol } \\
\text { concentration must be used when there } \\
\text { is no soap and water. }\end{array}$ \\
\hline 19 & General & $\begin{array}{l}\text { Social and individual } \\
\text { behaviors due to } \\
\text { coronavirus } \\
\text { pandemic }\end{array}$ & $\begin{array}{l}\text { *Exposure to coronavirus } \\
\text { pandemic. } \\
* * \text { Infection, disability, death. }\end{array}$ & $\begin{array}{l}\text { It has been found that } \\
\text { social communication } \\
\text { among employees is } \\
\text { not appropriate for } \\
\text { pandemic prevention } \\
\text { rules. }\end{array}$ & 4 & 5 & 20 & $\begin{array}{l}\text { Shaking hands and kissing must be } \\
\text { prohibited; employees must avoid } \\
\text { touching their mouths, noses and eyes } \\
\text { with dirty hands; mouth and nose must } \\
\text { be covered by single-use napkin when } \\
\text { coughing and sneezing, and inside of } \\
\text { the elbow must be used if there is no } \\
\text { napkin to be used. }\end{array}$ \\
\hline 20 & General & $\begin{array}{l}\text { Lack of hygiene } \\
\text { equipment among } \\
\text { coronavirus } \\
\text { measures }\end{array}$ & $\begin{array}{l}\text { *Exposure to coronavirus } \\
\text { pandemic. } \\
\text { **Infection, disability, death. }\end{array}$ & $\begin{array}{l}\text { Covid-19 virus, which } \\
\text { spreads very rapidly, } \\
\text { has been declared a } \\
\text { pandemic by WHO. }\end{array}$ & 4 & 5 & 20 & $\begin{array}{l}\text { All equipment requiring hygiene } \\
\text { (glasses, towels, etc.) must be personal } \\
\text { and not used in common. Manual } \\
\text { washing must be avoided, and dishes } \\
\text { must be washed in the dishwasher. }\end{array}$ \\
\hline 21 & General & $\begin{array}{l}\text { Emergencies } \\
\text { (Explosion, fire, etc.) }\end{array}$ & $\begin{array}{l}\text { *Emergency lights are } \\
\text { insufficient. }\end{array}$ & $\begin{array}{l}\text { Emergency lights are } \\
\text { insufficient. }\end{array}$ & 4 & 4 & 16 & $\begin{array}{l}\text { Emergency lights must be installed in } \\
\text { locations with deficient lighting. }\end{array}$ \\
\hline & & & $\begin{array}{l}* * \text { Serious injury, long-term } \\
\text { treatment. }\end{array}$ & & & & & \\
\hline 22 & General & Fire & $\begin{array}{l}\text { *Insufficient number of fire } \\
\text { extinguishers. } \\
\text { **Fire, serious injury. }\end{array}$ & $\begin{array}{l}\text { There are no fire } \\
\text { extinguishers in } \\
\text { certain areas marked } \\
\text { with signs. }\end{array}$ & 4 & 4 & 16 & $\begin{array}{l}\text { Fire extinguishers in areas marked with } \\
\text { signs must be completed. }\end{array}$ \\
\hline
\end{tabular}


Table 6. (Continued)

\begin{tabular}{|c|c|c|c|c|c|c|c|c|}
\hline No & Department & Hazard & $*$ Probability / **Risk & Current Situation & $\mathrm{P}$ & $\mathrm{S}$ & R S & $\begin{array}{c}\text { Recommendations/Measures to be } \\
\text { Taken }\end{array}$ \\
\hline 23 & General & Fire & $\begin{array}{l}\text { *Smoke sensor systems not } \\
\text { operating. } \\
\text { **Fire, serious injury. }\end{array}$ & $\begin{array}{l}\text { Some smoke sensors } \\
\text { are defective. }\end{array}$ & 4 & 4 & 16 & $\begin{array}{l}\text { Smoke sensor systems must be checked } \\
\text { and replaced (if necessary) in periodic } \\
\text { intervals. }\end{array}$ \\
\hline 24 & General & Fire & $\begin{array}{l}\text { *Fire alarm buttons not } \\
\text { operating. } \\
\text { **Fire, serious injury. }\end{array}$ & $\begin{array}{l}\text { The fire alarm button } \\
\text { in the storage } \\
\text { department is not } \\
\text { working. }\end{array}$ & 4 & 4 & 16 & $\begin{array}{l}\text { Fire alarm buttons must be checked and } \\
\text { made operational in periodic intervals. }\end{array}$ \\
\hline 25 & General & $\begin{array}{l}\text { Moving vehicles and } \\
\text { machines }\end{array}$ & $\begin{array}{l}\text { *Lack of iron guardrail in the } \\
\text { front part of the pallet truck. } \\
* * \text { Serious injury, long-term } \\
\text { treatment. }\end{array}$ & $\begin{array}{l}\text { There is no iron } \\
\text { guardrail in the front } \\
\text { part of the pallet truck. }\end{array}$ & 4 & 4 & 16 & $\begin{array}{l}\text { Appropriate guardrails must be } \\
\text { installed on the front part of the pallet } \\
\text { truck. }\end{array}$ \\
\hline 26 & Shipping & Chemical substances & $\begin{array}{l}\text { *Lack of MSDS forms of } \\
\text { chemicals used. } \\
* * \text { Serious injury, burn, } \\
\text { occupational disease. }\end{array}$ & $\begin{array}{l}\text { There are no MSDS } \\
\text { forms for chemical } \\
\text { substances where they } \\
\text { are stored. }\end{array}$ & 4 & 4 & 16 & $\begin{array}{l}\text { MSDS data sheets of all chemical } \\
\text { substances must be hang where the } \\
\text { chemical substances are stored at. }\end{array}$ \\
\hline 27 & Shipping & Chemical substances & $\begin{array}{l}\text { *Insufficient ventilation. } \\
* * \text { Occupational disease. }\end{array}$ & $\begin{array}{l}\text { Insufficient } \\
\text { ventilation in } \\
\text { serigraphy section. }\end{array}$ & 4 & 4 & 16 & $\begin{array}{l}\text { Ventilation in serigraphy section must } \\
\text { be reinforced according to standards. }\end{array}$ \\
\hline 28 & C Line & $\begin{array}{l}\text { Chemical substances } \\
\text { suspended in the air }\end{array}$ & $\begin{array}{l}\text { *Insufficient ventilation. } \\
* * \text { Occupational disease. }\end{array}$ & $\begin{array}{l}\text { Ventilation is not } \\
\text { sufficient in C line } \\
\text { section. }\end{array}$ & 4 & 4 & 16 & $\begin{array}{l}\text { Ventilation system in } \mathrm{C} \text { line press } \\
\text { section must be reinforced according to } \\
\text { standards. }\end{array}$ \\
\hline 29 & C Line & $\begin{array}{l}\text { Faulty storage } \\
\text { (Feeding point) }\end{array}$ & $\begin{array}{l}\text { *Not using the apparatus to } \\
\text { prevent falling of glasses. } \\
\text { **Serious injury, long-term } \\
\text { treatment due to falling of } \\
\text { glasses. }\end{array}$ & $\begin{array}{l}\text { Employees do not use } \\
\text { the apparatus to } \\
\text { prevent falling of } \\
\text { glasses despite they } \\
\text { are available. }\end{array}$ & 4 & 4 & 16 & $\begin{array}{l}\text { Employees must be trained in terms of } \\
\text { using the apparatus to prevent falling of } \\
\text { glasses as well as providing required } \\
\text { warnings/notices. }\end{array}$ \\
\hline 30 & A Line & $\begin{array}{l}\text { Moving vehicles and } \\
\text { machines (piston in } \\
\text { the corner turning } \\
\text { point in line A) }\end{array}$ & $\begin{array}{l}\text { *Not using protective enclosures } \\
\text { of machinery and equipment. } \\
\text { **Jamming of limbs, serious } \\
\text { injury. }\end{array}$ & $\begin{array}{l}\text { Protective enclosures } \\
\text { of the machine are not } \\
\text { used. }\end{array}$ & 4 & 4 & 16 & $\begin{array}{l}\text { Awareness trainings must be provided } \\
\text { to employees in order to prevent } \\
\text { jamming of limbs of personnel in the } \\
\text { movement area of the pistons. }\end{array}$ \\
\hline 31 & $\begin{array}{l}\text { New Panel } \\
\text { Department }\end{array}$ & $\begin{array}{l}\text { Moving vehicles and } \\
\text { machines (Rinsing } \\
\text { machine) }\end{array}$ & $\begin{array}{l}\text { *Not using protective enclosures } \\
\text { of machinery and equipment. } \\
* * \text { Serious injury, long-term } \\
\text { treatment. }\end{array}$ & $\begin{array}{l}\text { The machine does not } \\
\text { have protective } \\
\text { enclosures. }\end{array}$ & 4 & 4 & 16 & $\begin{array}{l}\text { The new board rinsing line must be } \\
\text { enclosed with fence to prevent possible } \\
\text { accident risks. }\end{array}$ \\
\hline 32 & Rohmer & $\begin{array}{l}\text { Moving vehicles and } \\
\text { machines (Rohmer } \\
\text { machine) }\end{array}$ & $\begin{array}{l}\text { *Not using protective enclosures } \\
\text { of machinery and equipment. } \\
* * \text { Serious injury, long-term } \\
\text { treatment. }\end{array}$ & $\begin{array}{l}\text { The machine does not } \\
\text { have protective } \\
\text { enclosures. }\end{array}$ & 4 & 4 & 16 & $\begin{array}{l}\text { Rohmer machine must be enclosed with } \\
\text { fence to prevent unauthorized } \\
\text { intervention. }\end{array}$ \\
\hline 33 & $\begin{array}{l}\text { Pressing } \\
\text { Room }\end{array}$ & $\begin{array}{l}\text { Chemical substances } \\
\text { suspended in the air }\end{array}$ & $\begin{array}{l}\text { *Insufficient ventilation. } \\
\text { **Occupational disease. }\end{array}$ & $\begin{array}{l}\text { Ventilation system is } \\
\text { not sufficient. }\end{array}$ & 4 & 4 & 16 & $\begin{array}{l}\text { Appropriate ventilation system must be } \\
\text { installed in board press chamber. }\end{array}$ \\
\hline 34 & General & $\begin{array}{l}\text { Crash } \\
\text { (Walkways inside } \\
\text { the factory) }\end{array}$ & $\begin{array}{l}\text { *Deformation on paints of } \\
\text { walkways and forklift ways. } \\
\text { **Serious injury, long-term } \\
\text { treatment. }\end{array}$ & $\begin{array}{l}\text { Paints of walkways } \\
\text { and forklift ways are } \\
\text { faded. }\end{array}$ & 4 & 4 & 16 & $\begin{array}{l}\text { Walkways and forklift ways must be } \\
\text { painted and made apparent. }\end{array}$ \\
\hline 35 & $\begin{array}{l}\text { Maintenance } \\
\text { Department }\end{array}$ & $\begin{array}{l}\text { Moving vehicles and } \\
\text { machines (Spiral } \\
\text { machine) }\end{array}$ & $\begin{array}{l}* \text { Protective enclosure of the } \\
\text { machinery equipment not being } \\
\text { mounted. } \\
* * \text { Serious injury. }\end{array}$ & $\begin{array}{l}\text { The machine has } \\
\text { protective enclosures, } \\
\text { but not mounted. }\end{array}$ & 4 & 4 & 16 & $\begin{array}{l}\text { Protective enclosure must be mounted } \\
\text { on the spiral machine, and machine } \\
\text { equipment without protective } \\
\text { enclosures must not be operated. }\end{array}$ \\
\hline 36 & Production & $\begin{array}{l}\text { Moving vehicles and } \\
\text { machines }\end{array}$ & $\begin{array}{l}\text { *Cutting tools and equipment } \\
\text { left in the open. } \\
\text { *Injury due to cuts. }\end{array}$ & $\begin{array}{l}\text { Protective handles are } \\
\text { available, but not } \\
\text { mounted. }\end{array}$ & 5 & 3 & 15 & $\begin{array}{l}\text { Use of cutting equipment without } \\
\text { protective handles must be prevented, } \\
\text { and the personnel must be informed. }\end{array}$ \\
\hline 37 & $\begin{array}{l}\text { A-B End-of- } \\
\text { Line } \\
\text { Pressing } 2\end{array}$ & Electricity & $\begin{array}{l}\text { *Dripping of water from the } \\
\text { discharge system of the air } \\
\text { conditioner next to the electrical } \\
\text { board. } \\
\text { *Electric shock, serious injury, } \\
\text { burn. }\end{array}$ & $\begin{array}{l}\text { The water dripping } \\
\text { from discharge hose } \\
\text { of the air conditioner } \\
\text { causes the insulating } \\
\text { mats under the electric } \\
\text { boards to lose their } \\
\text { functions. }\end{array}$ & 5 & 3 & 15 & $\begin{array}{l}\text { Discharge hose of the air conditioner } \\
\text { must be checked to prevent leakage. }\end{array}$ \\
\hline
\end{tabular}




\section{References}

[1] B. O. Alli, Fundamental Principles of Occupational Health and Safety (2nd ed.). International Labor Organization, Geneva, 2008.

[2] Say1: 28512, İş Sağlığı ve Güvenliği Risk Değerlendirmesi Yönetmeliği. Resmi Gazete, 29 Aralık 2012.

[3] R. Sankila, S. Karjalainen, E. Pukkala, H. Oksanen, T. Hakulinen, L. Teppo and M. Hakama, Cancer risk among glass factory workers: an excess of lung cancer. Occupational and Environmental Medicine, 47(12), 815-818, 1990.https://doi.org/10.1136/oem.47.12.815

[4] J. P. Shepherd, M. R. Brickley, D. Gallaghar and R. V. Walker, Risk of occupational glass injury in bar staff. Injury, 25(4), 219-220, 1994. https://doi.org/10.1016/ 0020-1383(94)90064-7

[5] G. Wingren and O. Axelson, Epidemiologie studies of occupational cancer as related to complex mixtures of trace elements in the art glass industry. Scandinavian Journal of Work, Environment \& Health, 19(1), 95-100, 1993.

[6] M. Rahman, G. Wingren and O. Axelson, Diabetes mellitus among Swedish art glass workers-an effect of arsenic exposure?. Scandinavian Journal of Work, Environment \& Health, 22(2), 146-149, 1996.

[7] D. Bartoli, G. Battista, M. De Santis, T. E. Iaia, D. Orsi, M. Tarchi and M. Valiani, Cohort study of art glass workers in Tuscany, Italy: mortality from nonmalignant diseases. Occupational Medicine, 48(7), 441445, 1998. https://doi.org/10.1093/occmed/48.7.441

[8] R. Pirastu, D. Bartoli, G. Battista, M. De Santis, T. Iaia, D. Orsi and M. Valiani, Cancer mortality of art glass workers in Tuscany, Italy. Scandinavian Journal of Work, Environment \& Health, 24(5), 386-391, 1998.

[9] J. Bazroy, G. Roy, A. Sahai and M.B. Soudarssanane, Magnitude and risk factors of injuries in a glass manufacturing plant. Environmental and Occupational Health Practice, 45(1), 53-59, 2003. https://doi.org/ 10.1539/joh.45.53

[10] K. Tarvainen, R. Jolanki, L. Forsman-Grönholm, T. Estlander, P. Pfäffli, J. Juntunen and L. Kanerva, Exposure, skin protection and occupational skin diseases in the glass-fibre-reinforced plastics industry. Contact Dermatitis, 29(3), 119-127, 1993 https://doi.org/10.1111/j.1600-0536.1993.tb03508.x

[11] J. G. M. Van Rooij, A. Kasper, G. Triebig, P. Werner, F. J. Jongeneelen and H. Kromhout, Trends in occupational exposure to styrene in the European glass fibre-reinforced plastics industry. Annals of Occupational Hygiene, 52(5), 337-349, 2008. https://doi.org/10.1093/annhyg/men020

[12] L. Lipworth, C. La Vecchia, C. Bosetti and J. K. McLaughlin, Occupational exposure to rock wool and glass wool and risk of cancers of the lung and the head and neck: A systematic review and meta-analysis. Journal of Occupational and Environmental Medicine, 51(9), 1075-1087, 2009. https://doi.org/10.1097/jom. 0b013e3181b35125
[13] K. Cummnigs, Techniques of Kiln-Formed Glass (1st ed.). University of Pennsylvania Press, Philadelphia, 1997.

[14] E. Çakmak, Atölye tipi üretim yapan sanayi işletmelerinde iş sağlığı ve güvenliği. Çalışma ve Sosyal Güvenlik Eğitim Uzmanlığı Tezi, T.C. Çalışma ve Sosyal Güvenlik Bakanlığı, Ankara, Türkiye, 2014.

[15] Meslek Hastalıkları ve İş ile İlgili Hastalıklar Tanı Rehberi. T.C. Çalışma ve Sosyal Güvenlik Bakanlı̆̆ı, Ankara, 2011.

[16] Türkiye Cam ve Cam Ürünleri Sanayi Meclisi Sektör Raporu. Türkiye Odalar ve Borsalar Birliği, Ankara, 2012.

[17] ITC-TRADE MAP, Trade statistics for international business development. https://www.trademap.org/ country_selproductcountry_ts.aspx?nvpm $=1 \% 7 \mathrm{c} 792 \%$ 7c\%7c\%7c\%7c70\%7c\%7c\%7c2\%7c1\%7c1\%7c1\%7c $2 \% 7 \mathrm{c} 1 \% 7 \mathrm{c} 2 \% 7 \mathrm{c} 1 \% 7 \mathrm{c} 1$, Accessed 3 February 2021.

[18] R. Lay and G. Strasser, Risk Management of Complex, Technology Based Systems: Observations on similarities and differences. in Risk Assessment and Management. Advances in Risk Analysis, vol 5. L. B. Lave, (Eds.) Boston: Springer, 179-188, 1987. https://doi.org/10.1007/978-1-4757-6443-7_20

[19] J. Ansell and F. Wharton, Risk Analysis Assessment and Management. John Wiley \& Sons, West Sussex, 1992.

[20] E. V. Tarasova, E. N. Nikulina, E. Nikolaevna and N. V. Moskvicheva, Analysis of risk assessment methods of innovative projects. Revista Espacios, 38(49), 18-34, 2017.

[21] S. Tweneboah-Koduah and W. J. Buchanan, Security risk assessment of critical infrastructure systems: A comparative study. The Computer Journal, 61(9), 13891406, 2018. https://doi.org/10.1093/comjnl/bxy002

[22] M. Ersoy, M. Y. Çelik, L. Yeşilkaya and O. Çolak, Combination of Fine-Kinney and GRA methods to solve occupational health and safety problems. Journal of the Faculty of Engineering and Architecture of Gazi University, 34(2), 751-770, 2019. https://doi.org/10. 17341/gazimmfd.416534

[23] A. Oulehlová, Risk management of hazardous activities in the Czech Republic. Védelem Tudomány - IV. évfolyam, Iparbiztonság Különszám, 2019(2), 1-28, 2019.

[24] A. Özçelik, İş sağlığı ve güvenliğinde Kinney yöntemiyle risk yönetimi: Mermer işletmesi örneği. Yüksek Lisans Tezi, Eskişehir Osmangazi Üniversitesi, Eskişehir, Türkiye, 2013.

[25] Ö. Özkılıç, İş Sağlığı ve Güvenliği, Yönetim Sistemleri ve Risk Değerlendirme Metodolojileri. Türkiye İşverenler Sendikası Konfederasyonu (TİSK), Ankara, 2005.

[26] Sayı: 28339, İş Sağlığı ve Güvenliği Kanunu. Resmi Gazete, 30 Haziran 2012.

[27] Yayın No:140, 5 Adımda Risk Değerlendirmesi. T.C. Çalışma ve Sosyal Güvenlik Bakanlığı, Ankara, 2007.

[28] A. Navidian, Z. Rostami and N. Rozbehani, Effect of motivational group interviewing-based safety education 
on workers' safety behaviors in glass manufacturing. BMC Public Health, 15(1), 929, 2015. https://doi.org/ 10.1186/s12889-015-2246-8

[29] E. Ocaktan, İşçilerin sağlığı ve güvenliği için meslek hastalıkları, eğitim ve atölye. II. Sağlık Ekonomisi Kongres, sayfa 11-15, Ankara, Türkiye, 4-5 Aralık 2014.

[30] K. Çınar, Cam üretim sektöründe termal konfor şartlarının değerlendirilmesi. İş Sağlığı ve Güvenliği Uzmanlık Tezi, Çalışma ve Sosyal Güvenlik Bakanlığı, Ankara, 2016.

[31] J. Bender, J. G. Hadley, J. P. Hellerstein and C. M. Hohman, Glass, pottery and related materials. Encyclopedia of Occupational Health and Safety, 225263, 2011.

[32] Meslek Hastalıkları ve İş ile İlgili Hastalıklar Tanı Rehberi. T.C. Çalışma ve Sosyal Güvenlik Bakanlı̆̆ı, Ankara, 2011.

[33] G. Ekuklu, A. Saltık and M. Yaman, Industrial dust problem due to total dust measurement in glass factory environment in Kirklareli. Working Environment Journal, 39, 13-20, 1998.

[34] Ş. T. Azgın, N. Kekecoğlu and E. Yamac, Evaluation of the air quality and $\mathrm{CO} 2$-equivalent change of Kayseri during the Covid-19 outbreak. NOHU Journal of Engineering Sciences, 10(1), 9-15, 2021. https://doi. org/10.28948/ngumuh.811079
[35] I. F. Zulheir, Encyclopaedia of Occupational Health and Safety (4th ed.). International Labor Organization, Geneva, 1998.

[36] E-Fact 53-Risk Assessment for Biological Agents. European Agency for Safety and Health at Work (EUOSHA), 2010.

[37] Ç. Üstün and S. Özçiftçi, Effects of Covid-19 pandemic on social life and ethical plane: An evaluation study. Anatolian Clinic the Journal of Medical Sciences, 25(1), 142-153, 2020. https://doi.org/10.21673/ anadoluklin.721864

[38] H. Akarsu, B. Ayan, E. Çakmak, B. Doğan, D. Boz Eravc1, E. Kahraman and D. Koçak, Relationship between psychosocial risk factors in the workplace and work related disease, occupational disease and work accident. Journal of Social Insurance, 14, 28-62, 2018. https://doi.org/10.21441/sguz.2018.68

[39] M. N. İlhan, Occupational Health and Safety. Ataturk University Open Education Faculty, Erzurum, 2015.

[40] M. P. Rowan and C. P. Wright, Ergonomics is good for business. Work Study, 43(8), 7-12, 1994. https://doi. org/10.1108/EUM0000000004015

[41] J. E. Fernandez, Ergonomics in the workplace. Facilities, 13(4), 20-27, 1995. https://doi.org/ $10.1108 / 02632779510083359$ 